\title{
Standard Body Weight and Serum Estradiol and Progesterone Concentrations in Response to Total Lysine Content in Female Broiler Breeders from 14 to 42 Days after Hatch
}

-Author(s)
Kim $\mathrm{E}^{\star}$
Rew HJ"
Shin TK"
Cho HM'
Wickramasuriya SS'
Yi YJ"
Jeong J"
Choi I"
Heo JM"
' Department of Animal Science and
Biotechnology, Chungnam National
University, Daejeon 34134, South Korea,
" Division of Biotechnology, College of
Environmental and Bioresource Sciences,
Chonbuk National University, Iksan 54596,
Jeonbuk, South Korea
*These authors have contributed equally to
this work

\section{nail Address}

Corresponding author e-mail address Jung Min Heo

Department of Animal Science and Biotechnology, Chungnam National University 34134, Republic of Korea Daejeon, Daejeon, 34134 - South Korea. Tel: $\quad$ +82428215777 Email: jmheo@cnu.ac.kr

\section{aKeywords}

Broiler breeder, linear-plateau model, nutritional response model, quadraticplateau model, total lysine.

\section{ABSTRACT}

This study was conducted to determine the total lysine requirement for female broiler breeders from days 14 to 42. Two-hundred and ten female broiler breeders were used in a completely randomized design with 6 replicates per treatment and 5 chicks per pen under restricted feeding. The contents of total lysine used in this experiment were 0.68 , $0.72,0.76,0.80,0.84,0.88$ and $0.92 \%$ in the diet. A basal diet was formulated to meet or to exceed the Ross 308 female broiler breeders' nutrient specifications except for the lysine. Body weight and feed intake were measured to calculate feed efficiency, and body weight uniformity was defined on a weekly basis. One chick per pen was randomly selected to collect blood samples, organ and an abundance of sexual maturity associated miRNAs (miR-21, mi-26a and mi-375) in the plasma was measured on day 42 . Increasing total lysine contents in the diet improved body weight gain and feed conversion ratio from days 14 to 42 . The combined values from the two models for BW, average daily gain and feed efficiency were estimated at 1.04, 1.00 and $1.21 \%$ total lysine, respectively. Total lysine contents did not affect the ovary weight, serum estradiol-17 $\beta$, serum progesterone and plasma urea nitrogen or the expression levels of the three miRNAs on day 42. Therefore, the results from the current study indicated that female broiler breeders fed on $0.68 \%$ total lysine could achieve the recommended BW, suggested by field practice when data were fitted into the overlapped point of linear-, and quadratic-plateau models.

\section{INTRODUCTION}

Lysine is an indispensable nutrient for farm animals, although it is the second-limiting amino acid when diets are formulated mainly with corn and soybean meal for poultry ration. In addition, the diets with either deficient or excessive lysine caused poor performance and (or) increased the feed cost in broilers (Dozier et al., 2010; Mehri et al., 2010).

Owing to genetically higher growth potential in meat-type breeder hens, they are generally subjected to feed restriction to control their obesity and (or) to meet their target body weight (BW). Over or under BW is strongly related to poor reproductive performance of female broiler breeders including ovarian dysfunction and diabetes, were associated with metabolic imbalance (Robinson et al., 1993; Chen et al., 2006; Mohiti-Asli et al., 2012a). Chen et al. (2006) described that 50 to $60 \%$ of daily ad libitum feed reduced metabolic disease, and enhanced egg quality in female broiler breeders. In this regard, commercial broiler breeder feeds are formulated with low energy and crude protein levels (Ekmay et al., 2014). For instance, when the diets contained excess lysine, it could result in a higher muscle deposition 
Kim E, Rew HJ, Shin TK, Cho HM, Wickramasuriya SS, Yi YJ, Jeong J, Choi I, Heo JM
Standard Body Weight and Serum Estradiol and Progesterone Concentrations in Response to Total Lysine Content in Female Broiler Breeders from 14 to 42 Days after Hatch

Experimental design: This experiment was conducted in a completely randomized design with 7 total lysine levels. The 7 total lysine levels used in this experiment were $0.68,0.72,0.76,0.80,0.84,0.88$ and $0.92 \%$. The chicks were randomly allotted in 42 pens with 5 birds per pen under standard management conditions. Birds had a 2-week adaptation period to prevent the adverse effects on early starter phase before the beginning of the study. Birds were fed with the respective experimental diets from 14 to 42 days. All experimental diets were fed as crumble form, and the study lasted for 28 days.

Birds, housing and diets: Two hundreds and ten 1-day-old Ross308 female broiler breeders were obtained from a commercial hatchery (Eum-seong chicken farm, Eumseong-gun, Chungcheongbuk-do, Korea). At the beginning, birds were randomly divided into 7 treatments with 6 replicates having 5 birds in each pen. This experiment was conducted from April to May 2016. Seven treatments were formulated to meet and exceed Ross 308 parent stock nutrition specification except for lysine (Aviagen, 2013). Experimental diets contained total lysine content from $0.68 \%$ to $0.92 \%$ in $0.04 \%$ increment (Table 1). From day 1 to 14 , birds were fed with common commercial starter diet $(2,800 \mathrm{kcal} /$

Table 1 - Composition of experimental diets (\% as fed)

\begin{tabular}{|c|c|c|c|c|c|c|c|}
\hline \multirow{2}{*}{ Item } & \multicolumn{7}{|c|}{ Total lysine, \% } \\
\hline & 0.68 & 0.72 & 0.76 & 0.80 & 0.84 & 0.88 & 0.92 \\
\hline Corn & 48.84 & 47.84 & 46.24 & 57.77 & 56.27 & 54.57 & 53.27 \\
\hline Wheat & 15.00 & 14.60 & 14.60 & - & - & - & - \\
\hline Wheat bran & 17.00 & 17.00 & 17.00 & 17.00 & 17.00 & 17.00 & 17.00 \\
\hline Soybean meal & 14.00 & 15.40 & 17.00 & 19.50 & 21.00 & 22.70 & 24.00 \\
\hline Vegetable oil & 1.00 & 1.00 & 1.00 & 1.30 & 1.30 & 1.30 & 1.30 \\
\hline Limestone & 1.50 & 1.50 & 1.50 & 1.50 & 1.50 & 1.50 & 1.50 \\
\hline Monocalcium Phosphate & 1.80 & 1.80 & 1.80 & 1.80 & 1.80 & 1.80 & 1.80 \\
\hline Salt & 0.30 & 0.30 & 0.30 & 0.30 & 0.30 & 0.30 & 0.30 \\
\hline Vitamin-Mineral premix ${ }^{1}$ & 0.30 & 0.30 & 0.30 & 0.30 & 0.30 & 0.30 & 0.30 \\
\hline L-Arginine & 0.04 & 0.04 & 0.04 & - & - & - & - \\
\hline DL-Methionine & 0.11 & 0.11 & 0.11 & 0.26 & 0.26 & 0.26 & 0.26 \\
\hline L-Threonine & 0.05 & 0.05 & 0.05 & 0.12 & 0.12 & 0.12 & 0.12 \\
\hline L-Isoleucine & 0.02 & 0.02 & 0.02 & 0.06 & 0.06 & 0.06 & 0.06 \\
\hline L-Valine & 0.04 & 0.04 & 0.04 & 0.09 & 0.09 & 0.09 & 0.09 \\
\hline \multicolumn{8}{|l|}{ Calculated composition² } \\
\hline $\mathrm{ME}, \mathrm{kcal} / \mathrm{kg}^{3}$ & 2,800 & 2,800 & 2,800 & 2,800 & 2,800 & 2,800 & 2,800 \\
\hline Crude protein, \% & 18.0 & 18.1 & 18.1 & 18.0 & 18.0 & 17.9 & 18.0 \\
\hline Calcium, \% & 1.0 & 1.1 & 1.1 & 1.1 & 1.1 & 1.1 & 1.1 \\
\hline Available Phosphate, \% & 0.5 & 0.5 & 0.5 & 0.4 & 0.5 & 0.5 & 0.5 \\
\hline Total lysine, \% & 0.68 & 0.72 & 0.76 & 0.80 & 0.84 & 0.88 & 0.92 \\
\hline
\end{tabular}

Provided the following nutrients (per kg of air-dry diet): Vitamins: A 12,000 IU, D 33,000 IU, E $15 \mathrm{mg}, \mathrm{K} 2 \mathrm{mg}$, thiamine $2 \mathrm{mg}$, riboflavin $6 \mathrm{mg}$, pyridoxine $2 \mathrm{mg}$, calcium pantothenate $0.03 \mathrm{mg}$, folic acid $0.2 \mathrm{mg}$, niacin $45 \mathrm{mg}$, biotin $0.15 \mu \mathrm{g}$. Minerals: calcium $0.5 \%$, Co $0.5 \mathrm{mg}$ (as cobalt sulphate), Cu10 mg (as copper sulphate), iodine $0.9 \mathrm{mg}$ (as potassium iodine), iron $80 \mathrm{mg}$ (as ferrous sulphate), Mn $80 \mathrm{mg}$ (as manganous oxide), Se $0.2 \mathrm{mg}$ (as sodium selenite), Zn $80 \mathrm{mg}$ (as zinc oxide).

${ }^{2}$ The values are calculated according to the values of feedstuffs in NRC (1994).

${ }^{3} \mathrm{ME} ;$ Metabolizable energy. 
Kim E, Rew HJ, Shin TK, Cho HM, Wickramasuriya SS, Yi YJ, Jeong J, Choi I, Heo JM
Standard Body Weight and Serum Estradiol and Progesterone Concentrations in Response to Total Lysine Content in Female Broiler Breeders from 14 to 42 Days after Hatch

Data collection: To monitor BW and average daily gain (ADG), all birds were weighed weekly from the $14^{\text {th }}$ to the $42^{\text {nd }}$ day of age. The mortality was recorded daily and the feed conversion ratio (FCR) and BW uniformity were calculated every week.

Chemical analyses: At the conclusion of the experiment, a selected bird from each replicate pen was bled for plasma metabolites and serum hormones analysis, and $3 \mathrm{~mL}$ of blood samples were collected from jugular vein into vacutainer and stored at $4{ }^{\circ} \mathrm{C}$ until the transfer to the laboratory. The serum and plasma separated by centrifugation at 3,000 rpm for 15 min (Micro 12, Hanil Science Co., Ltd., Korea) and then stored at $-20^{\circ} \mathrm{C}$ for the assay. Quantitative determinations of estradiol-17 $\beta$ and progesterone in the serum was conducted using electro chemiluminescent immune assay kits (Roche, Mannheim, Germany) and using a Cobas ${ }^{\circledR} 6000$ (e601 module) analyzer (Roche, Mannheim, Germany). Plasma urea nitrogen levels bleeding, ovaries were isolated and weighed.

Table 2 - Effect of total lysine content on body weight, average daily gain and feed conversion ratio of female broiler breeders from 14 to 42 days of age ${ }^{1}$

\begin{tabular}{|c|c|c|c|c|c|c|c|c|c|}
\hline \multirow{2}{*}{ Item } & \multicolumn{7}{|c|}{ Total lysine, \% } & \multirow{2}{*}{$\mathrm{SEM}^{2}$} & \multirow{2}{*}{$P$ value } \\
\hline & 0.68 & 0.72 & 0.76 & 0.80 & 0.84 & 0.88 & 0.92 & & \\
\hline \multicolumn{10}{|c|}{ Body weight (g) } \\
\hline Initial & 43.47 & 43.57 & 44.10 & 43.53 & 43.47 & 43.50 & 43.63 & 3.630 & 1.000 \\
\hline Day 14 & 257.57 & 256.30 & 258.30 & 257.33 & 257.77 & 256.30 & 253.30 & 11.052 & 0.993 \\
\hline Day 21 & $351.77^{a}$ & $353.63^{a}$ & $355.53^{a}$ & $360.90^{a b}$ & $368.13^{a b}$ & $373.70^{b}$ & $376.90^{b}$ & 15.432 & 0.008 \\
\hline Day 28 & $442.97^{a}$ & $448.87^{a b}$ & $451.57^{\mathrm{abc}}$ & $459.00^{\mathrm{bc}}$ & $464.80^{c d}$ & $478.00^{\text {de }}$ & $480.57^{e}$ & 17.083 & 0.001 \\
\hline Day 35 & $546.20^{a}$ & $559.33^{a b}$ & $566.30^{b}$ & $569.30^{b}$ & $589.00^{c}$ & $598.93^{c}$ & $602.07^{c}$ & 23.713 & 0.001 \\
\hline Day 42 & $656.33^{a}$ & $676.03^{a b}$ & $687.43^{b}$ & $692.37^{b c}$ & $716.06^{\mathrm{cd}}$ & $728.00^{d}$ & $725.93^{d}$ & 31.859 & 0.001 \\
\hline Day $14-42$ & $499.80^{a}$ & $511.50^{a b}$ & $514.73^{a b}$ & $526.78^{b c}$ & $531.56^{c}$ & $546.81^{d}$ & $547.98^{d}$ & 20.509 & 0.001 \\
\hline \multicolumn{10}{|c|}{ Daily lysine intake (mg) } \\
\hline Day 14 & 194 & 204 & 215 & 228 & 237 & 248 & 262 & & \\
\hline Day 21 & 217 & 229 & 242 & 255 & 268 & 280 & 293 & & \\
\hline Day 28 & 218 & 231 & 243 & 256 & 269 & 282 & 294 & & \\
\hline Day 35 & 249 & 263 & 278 & 293 & 308 & 322 & 336 & & \\
\hline Day 42 & 266 & 282 & 297 & 313 & 329 & 344 & 360 & & \\
\hline Day $14-42$ & 237 & 251 & 265 & 279 & 293 & 307 & 321 & & \\
\hline \multicolumn{10}{|c|}{ Average daily gain (g/bird/day) } \\
\hline Day $14-21$ & $18.84^{a}$ & $19.47^{a}$ & $19.45^{a}$ & $20.71^{a b}$ & $22.07^{b c}$ & $23.48^{\mathrm{cd}}$ & $24.71^{d}$ & 2.823 & 0.001 \\
\hline Day $22-28$ & $18.24^{\mathrm{a}}$ & $19.05^{\mathrm{ab}}$ & $19.121^{\mathrm{abc}}$ & $19.62^{\mathrm{abc}}$ & $19.33^{\mathrm{abc}}$ & $20.86^{a}$ & $20.73^{b c}$ & 1.511 & 0.019 \\
\hline Day $29-35$ & $20.65^{a}$ & $22.09^{\mathrm{ab}}$ & $22.95^{\mathrm{bc}}$ & $22.06^{\mathrm{ab}}$ & $24.84^{d}$ & $24.19^{\mathrm{cd}}$ & $24.30^{\mathrm{cd}}$ & 1.922 & 0.001 \\
\hline Day $36-42$ & 22.03 & 23.34 & 24.23 & 24.61 & 25.41 & 25.81 & 24.77 & 3.086 & 0.410 \\
\hline Day $14-42$ & $19.94^{\mathrm{a}}$ & $20.99^{a b}$ & $21.46^{b}$ & $21.75^{b c}$ & $22.91^{\mathrm{cd}}$ & $23.59^{d}$ & $23.63^{d}$ & 1.615 & 0.001 \\
\hline \multicolumn{10}{|c|}{ Feed conversion ratio $(\mathrm{g} / \mathrm{g}$ ) } \\
\hline Day 14-21 & $1.69^{c}$ & $1.67^{c}$ & $1.64^{c}$ & $1.54^{b c}$ & $1.46^{\mathrm{ab}}$ & $1.36^{a}$ & $1.29^{a}$ & 0.193 & 0.001 \\
\hline Day $22-28$ & $1.76^{c}$ & $1.70^{\mathrm{bc}}$ & $1.67^{\mathrm{abc}}$ & $1.63^{\mathrm{abc}}$ & $1.67^{\mathrm{abc}}$ & $1.54^{a}$ & $1.55^{\mathrm{ab}}$ & 0.131 & 0.019 \\
\hline Day 29-35 & $1.78^{c}$ & $1.66^{\mathrm{bc}}$ & $1.59^{a b}$ & $1.67^{b c}$ & $1.48^{a}$ & $1.52^{\mathrm{a}}$ & $1.51^{\mathrm{a}}$ & 0.137 & 0.001 \\
\hline Day 36-42 & 1.79 & 1.68 & 1.62 & 1.59 & 1.66 & 1.52 & 1.59 & 0.205 & 0.475 \\
\hline Day $14-42$ & $1.75^{d}$ & $1.68^{\mathrm{cd}}$ & $1.63^{b c}$ & $1.61^{b c}$ & $1.57^{\mathrm{ab}}$ & $1.48^{a}$ & $1.48^{\mathrm{a}}$ & 0.112 & 0.001 \\
\hline
\end{tabular}

'Results are mean with 6 replicates per treatment.

2Pooled standard error of mean.

a-fvalues in the same row with different superscripts differ significantly $(p<0.05)$. 
Kim E, Rew HJ, Shin TK, Cho HM, Wickramasuriya SS, Yi YJ, Jeong J, Choi I, Heo JM
Standard Body Weight and Serum Estradiol and Progesterone Concentrations in Response to Total Lysine Content in Female Broiler Breeders from 14 to 42 Days after Hatch were analyzed by Enzymatic assay method using Automatic Analyzer 7180 (Hitachi, Japan).

Analysis of miRNA expression: the miRNA was extracted from stored and pooled blood plasma samples using miRNeasy Serum/Plasma kit (Qiagen, Hilden, Germany) and reverse transcribed to CDNA using miScript II kit (Qiagen) with miScript HiFlex Buffer for quantification of mature miRNA and precursor miRNA. Quantitative real time polymerase chain reaction (qRT-PCR) was carried out utilizing a StepOnPlus realtime PCR system (SYBR Green Master Mix; Applied Biosystems, Foster (ity, (A, USA), and gene-specific primers (gga-miR-21 F; TAG CTT ATC AGA CTG ATG TTG, gga-miR-26a;TTC AAG TAA TCC AGG ATA GGC, gga-miR-375, F; TTT GTT CGT TCG GCT CGC GTT) and miScript Universal Primer (Qiagen). The relative quantification of gene expression was determined by the 2- $-\Delta \Delta \mathrm{Ct}$ method using $5 \mathrm{~S}$ rRNA as an internal control (F; 5-TCT CGT CTG ATC TCG GAA GC-3; R; 5-AGG AGG TCT CCC ATC CAA GT-3).

Statistical analyses: Data were subjected to ANOVA using the GLM procedure of IBM SPSS statistics 22 (SPSS Inc., Chicago, IL) as a completely randomized design. Replicate pen was used as the experimental unit for growth performance index, and individual birds were used as the experimental unit for ovary weight, blood parameters measured, and miRNA expression. Statistical significance was accepted at $p<0.05$. Linearplateau (LP) and quadratic-plateau (QP) models were fitted to estimate the optimal lysine requirement using a Nutritional Response Model (Version 1.1; Vedenov \& Pesti, 2008).

\section{RESULTS}

All the female broiler breeders used in the study were healthy and well-performed, and achieved or exceeded the Ross 308 female broiler breeder BW target profiles throughout the entire experimental period.

Growth: Increased total lysine contents had higher BW, ADG and improved FCR from days 14 to 42 in the female broiler breeders ( $p<0.05$; Table 2$)$. In order to achieve maximum BW, ADG and minimum FCR, total lysine requirement was to be $0.94 \%, 0.89 \%$ and $0.94 \%$, respectively, when data was fitted into LP regression model from 14 to 42 days of age in female broiler breeders (Figure 1, 2 and 3). However, QP model showed total lysine requirement for maximum BW and $A D G$, and for minimum FCR from 14 to 42 days of age were estimated to be $1.13,1.27$ and $1.48 \%$ of the

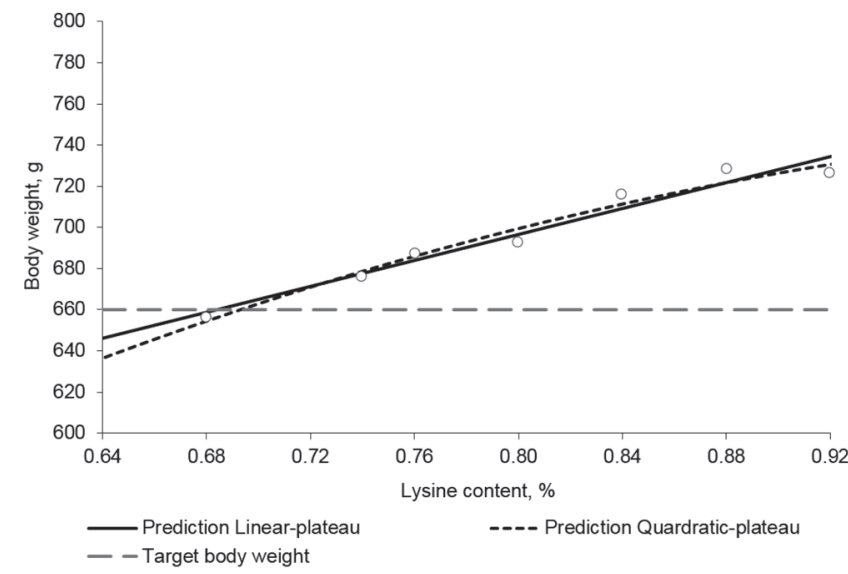

Figure 1 - Determination of total lysine requirement for maximum body weight based on linear- and quadratic-plateau model. Total lysine requirement for broiler breeders from 14 to 42 days of age for body weight determined by a quadratic-plateau model was 1.13 $\left[Y=752.93-477.47(1.13-x)^{2}, R^{2}=0.97\right]$ (open line), and by a linear-plateau was $0.94\left[Y=741.35-315.34(0.94-x), R^{2}=0.96\right]$ (closed line).Data points (0) represent least squares means of dietary treatment.

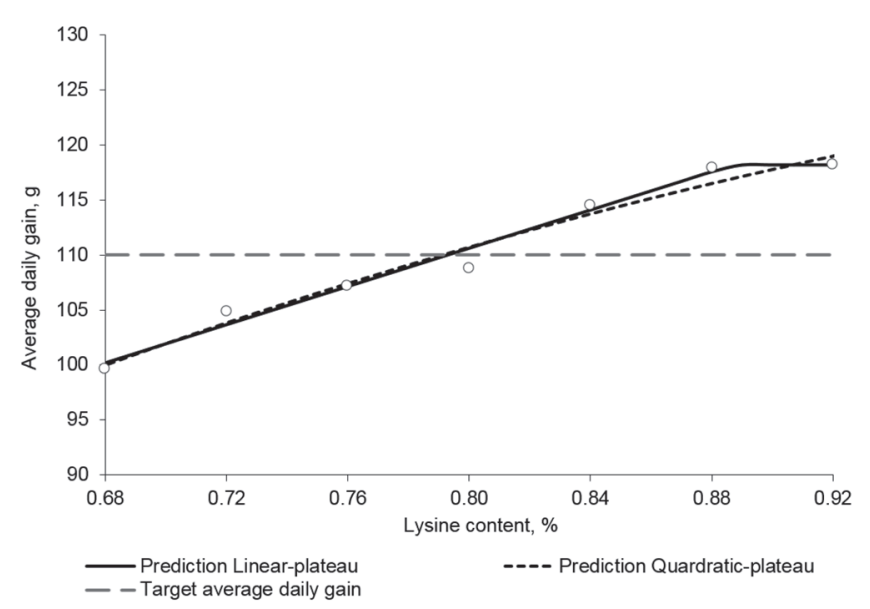

Figure 2 - Determination of total lysine requirement for maximum average daily gain based on linear- and quadratic-plateau model. Total lysine requirements of broiler breeders from 14 to 42 days of age for average daily gain determined by a quadratic-plateau model was $1.27\left[Y=129.22-84.7810(1.27-x) 2, R^{2}=0.97\right]$ (open line), and by a linear-plateau was $0.88\left[Y=118.16-86.86(0.88-x), R^{2}=0.98\right]$ (closed line). Data points (0) represent least squares means of dietary treatment.

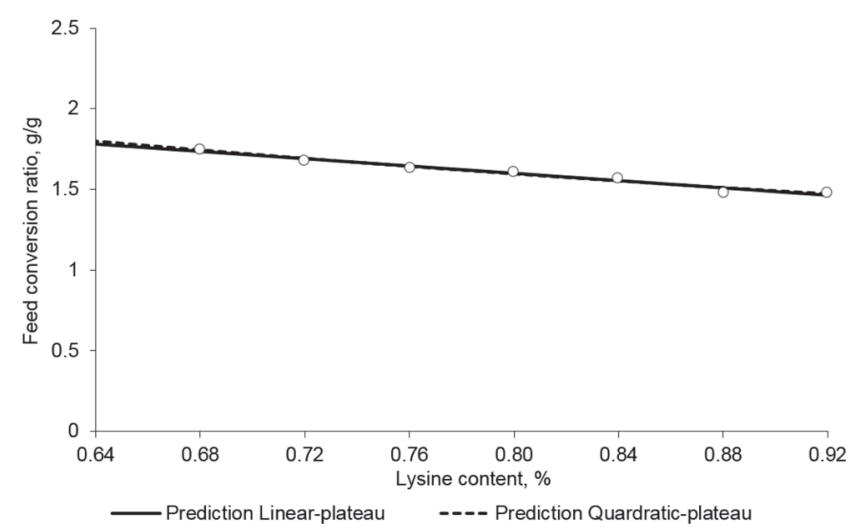

Figure 3 - Determination of total lysine requirement for minimum feed conversion ratio based on linear- and quadratic-plateau model. Total lysine requirements of broiler breeders from 14 to 42 days of age for feed conversion ratio determined by a quadratic-plateau model was $1.48\left[Y=1.21+0.83(1.48-x)^{2}, R^{2}=0.97\right]$ (open line), and by a linear-plateau was $0.94\left[Y=1.44+1.13(0.94-x), R^{2}=0.97\right]$ (closed line). Data points (0) represent least squares means of dietary treatment. 
Kim E, Rew HJ, Shin TK, Cho HM, Wickramasuriya SS, Yi YJ, Jeong J, Choi I, Heo JM
Standard Body Weight and Serum Estradiol and Progesterone Concentrations in Response to Total Lysine Content in Female Broiler Breeders from 14 to 42 Days after Hatch

Plasma metabolite, serum hormones and ovary weight: Female broiler breeders' visceral ovary weight and ovary weight correlated with BW by different total lysine levels are shown in Table 4. Total lysine levels did not affect ( $p>0.05$ ) both ovary weight and ovary weight correlated with BW. Serum hormones and plasma metabolite values at 42 days of age are presented in Table 5 . Total lysine levels did not affect $(p>0.05)$ serum estradiol-17 $\beta$, progesterone and plasma urea nitrogen concentrations.

Table 4 - Effect of total lysine content on ovary weight in female broiler breeders on day $42^{1}$

\begin{tabular}{lccc}
\hline Total lysine (\%) & $\begin{array}{c}\text { Daily lysine } \\
\text { intake }(\mathrm{mg})\end{array}$ & Ovary weight (g) & $\begin{array}{c}\text { Relative ovary } \\
\text { weight (\%) }\end{array}$ \\
\hline 0.68 & 237 & 0.092 & 0.014 \\
0.72 & 251 & 0.116 & 0.017 \\
0.76 & 265 & 0.153 & 0.022 \\
0.8 & 279 & 0.191 & 0.028 \\
0.84 & 293 & 0.21 & 0.03 \\
0.88 & 307 & 0.161 & 0.022 \\
0.92 & 321 & 0.167 & 0.023 \\
SEM & - & 0.098 & 0.014 \\
\hline$p$-value & - & 0.421 & 0.525 \\
\hline
\end{tabular}

${ }^{1}$ Results are mean with 6 replicates per treatment.

${ }^{2}$ Pooled Standard error of mean.

$3 \%$ = tissue weight $/ \mathrm{BW} \times 100$.

Table 5 - Effect of total lysine content on serum estradiol (E2) concentration, serum progesterone(P4) concentration and blood nitrogen urea (BUN) of female broiler breeders on day $42^{1}$

\begin{tabular}{|c|c|c|c|c|}
\hline Total lysine (\%) & Daily lysine intake $(\mathrm{mg})$ & Serum E2 ${ }^{3}(\mathrm{pg} / \mathrm{mL})$ & Serum P4 $(n g / m L)$ & $\mathrm{PUN}^{5}$ (mg/dL) \\
\hline 0.68 & 237 & 5.18 & 0.05 & 0.358 \\
\hline 0.72 & 251 & 5.75 & 0.043 & 0.345 \\
\hline 0.76 & 265 & 5.73 & 0.04 & 0.395 \\
\hline 0.80 & 279 & 5.45 & 0.048 & 0.288 \\
\hline 0.84 & 293 & 5.08 & 0.065 & 0.293 \\
\hline 0.88 & 307 & 7.00 & 0.063 & 0.303 \\
\hline 0.92 & 321 & 5.75 & 0.048 & 0.240 \\
\hline $\mathrm{SEM}^{2}$ & & 1.353 & 0.033 & 0.098 \\
\hline$p$-value & $\otimes$ & 0.381 & 0.936 & 0.359 \\
\hline
\end{tabular}

'Data represent means from 4 repetitions per treatment. ${ }^{2}$ Pooled Standard error of mean. ${ }^{3}$ Estradiol-17 $\beta$. ${ }^{4}$ Progesterone. ${ }^{5}$ Plasma urea nitrogen.

\section{Expression of miRNA associated with} sexual maturity: To examine whether different lysine treatments affect sexual maturity of female broiler breeders, levels of miRNAs that are associated with sexual maturity and circuiting in the body fluid were measured in the broilers treated with different lysine contents from $0.68 \%$ to $0.92 \%$. There were no differences $(p>0.05)$ of expression levels of three miRNAs, gga-miR-21, gga-miR-26a, and gga-miR-375, although ggamiR-21 was relatively abundant at 0.88 and 0.92 $\%$ of lysine (Figure 4).

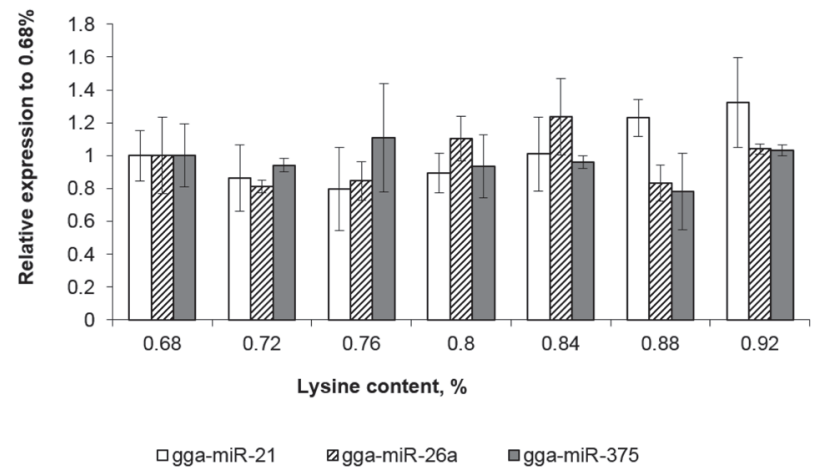

Figure 4 - Expression patterns of gga-miR-21a, gga-miR-26a, and gga-miR-375. The relative expression levels of miRNAs from blood plasma were determined by qRT-PCR. The expression levels were not significantly altered by Lysine contents on day 42 . However, gga-miR-21 was slightly elevated at 0.88 and $0.92 \%$, respectively $(p=0.045)$. 


\section{DISCUSSION}

In the present study, the levels of lysine requirement for optimum target BWs were investigated in female broiler breeders from 14 to 42 days of age. Also, reproductive organ weight, serum hormones, plasma urea nitrogen content, and circulating miRNAs were subsequently examined on day 42. For illustrative purposes, target performance objectives (i.e., BW, feed intake and etc.) for the Ross 308 Parent Stock female were used in this study (Aviagen, 2013).

Our results indicated that BW, ADG and FCR improved in a linear manner, as total lysine contents in the diet were increased. Harms \& Ivey (1992) conducted a study with Arbor Acres broiler breeder hens fed 7 levels of protein ranging from $9.6 \%$ to $12.2 \%$ and 7 levels of total lysine ranging from 0.37 to $0.56 \%$ those increased BW as both levels of protein and total lysine intake increased during the laying period. Likewise, Brito et al. (2017) evaluated the performance in male Cobb 500 broilers fed 4 different dietary lysine levels and broilers showed higher weight gains and improved feed efficiency as levels of lysine were increased during the growing period. Since the diets were given the same amount due to restricted feeding, an increase in BW of female broiler breeders would be driven by lysine to protein accretion. This is because lysine is primarily used for body protein synthesis and muscle development, and subsequent both nitrogen and muscle deposition in chickens (Scott et al., 1969; Sibbald et al., 1986; Si et al., 2001; Ball et al., 2007). In the present study, birds fed over $0.72 \%$ total lysine diets showed higher BW $(\geq 660 \mathrm{~g})$ than target BW, in turn, the birds fed $0.68 \%$ total lysine diet no overweight was observed, but similar with recommended $\mathrm{BW}$ in female broiler breeders on day 42. According to NRC (1994), recommendations for total lysine of female broiler breeder during the growing period were not presented due to insufficient research conducted to determine the broiler breeders' nutrient requirements from hatch to maturity (Powell \& Gehle, 1975; Harms \& Wilson, 1984). The Ross 308 Parent Stock Nutrient Specification (2013) reported 0.74\% of total lysine requirements for female breeders from 22 to 42 days of age. Our present study suggests that modern female broiler breeders may need less amount of lysine to achieve the target growth performance than that recommended by its company guideline. These gaps could be related to recent improvement in genetics and management practices over the decades that could yield significantly improved feed efficiency than the previous genotype (Rekaya et al., 2013; Reyer et al., 2015).
Total lysine requirements (i.e., total lysine level) of the female broiler breeders were evaluated through both LP and QP models from Nørgaard et al. (2015) and Wickramasuriya et al. (2016) in the current study. The mean values from two models were higher than established lysine levels of female broiler breeders when growth performances were compared to practical target growth performances. This is because these two models for nutrient recommendations are usually appropriate for determining maximum growth performance indices (Vednov \& Pesti, 2008). In this light, LP and QP models might not be suitable to determine the lysine requirement of female broiler breeders for optimal target growth performance, because BW of broiler breeders was already strictly controlled from an early age to reduce the reproductive problems in the future.

The coordinated activity of hypothalamic-pituitarygonadal axis manages the production of steroid hormones such as estradiol-17 $\beta$ and progesterone to develop the reproductive organs and initiate ovulation (Ethches, 1998; Onagbesan et al., 2006). Recently, intensive genetic selection for rapid growth rate has become a down trend due to a higher rate of lipolysis in broiler and relatively induced its obesity along with accumulation of adipose tissue in the ovary (Calabotta et al., 1985; Siiteri, 1987; Mohiti-Asli et al., 2012b). In the present study, all birds showed extremely lower concentrations $(<1 \mathrm{ng} / \mathrm{mL}$ ) of sexual serum hormones (i.e., estradiol-17ß and progesterone) on day 42. Tanabe et al. (1981) and Sharp (1975) reported that the sexual hormone levels were under $2 \mathrm{ng} / \mathrm{mL}$ from hatch to the $42^{\text {nd }}$ day, then it surged between 140 and 147 days of age. No changes in sexual hormones could be explained by the fact that the birds did not reach maturity to produce these hormones on day 42 . Thus, lower levels of estradiol-17 $\beta$ and progesterone may not have been enough to develop reproductive organ in this period. Consequently, further studies are warranted to accurately determine how sexual hormones and reproductive organs are altered by various lysine levels in female broiler breeders during growing- and (or) laying- period.

Furthermore, miRNAs associated with sexual maturity were examined. A previous study identified differentially expressed miRNAs (gga-miR1a, 21, 26a, 137 and 375) between days on 43 and 162 in chicken ovaries. For example, gga-miR-21 was elevated while gga-miR26a and gga-miR-375 were down-regulated in matured ovaries (Kang et al., 2013). Interestingly, it was observed that the expression of target miRNAs was not altered by the different lysine treatment, 
Kim E, Rew HJ, Shin TK, Cho HM, Wickramasuriya SS, Yi YJ, Jeong J, Choi I, Heo JM
Standard Body Weight and Serum Estradiol and Progesterone Concentrations in Response to Total Lysine Content in Female Broiler Breeders from 14 to 42 Days after Hatch suggesting that expression levels of circulating miRNAs in the body fluid can be an indicator for sexual maturity in the chicken.

Birds have no mechanisms for storage of amino acids and therefore when they had excessive amino acids, the amino acids are conveyed to the liver where they are immediately deaminated and (or) converted to urea (Goldstein \& Skadhauge, 2000; Weiner et al., 2014). With this in mind, concentration of blood urea nitrogen is strongly associated with the amount of amino acid intake along with its efficiency as then it could be used as an indirect measurement to estimate nitrogen utilization efficiency (Kohn et al., 2005; Donsbough et al., 2010). In the present study, increasing lysine levels did not alter plasma urea nitrogen concentration, which agrees with results of Corzo et al. (2003) and Dozier et al. (2010) in broiler. Donsbough et al. (2010) suggested the determination of differences in plasma urea nitrogen needed for fasting and refeeding schedules due to the above mentioned notion. However, female broiler breeders in the present study had $6 \mathrm{~h}$ feed deprivation before slaughtering and did not conduct fasting and refeeding.

\section{CONCLUSION}

In conclusion, the results of the present study indicated that female broiler breeders fed $0.68 \%$ total lysine diet could be able to reach the target BW more precisely than those fed upper levels of total lysine diets from 14 to 42 days of age.

\section{ACKNOWLEDGEMENT}

This work was financially supported by the research fund of Rural Development Administration, Republic of Korea (Project No. PJ011898).

\section{REFERENCES}

Aviagen. Ross 308 parent stock manual. 2013. Available from: http://en.aviagen.com/assets/TechCenter/Ross_PS/Ross_PS_ Handbook_2013_i-r1.pdf.

Ball RO, Urschel KL, Pencharz PB. Nutritional consequences of interspecies differences in arginine and lysine metabolism. The Journal of Nutrition 2007;137(6):1626-1641.

Bowmaker JE, Gous R. The response of broiler breeder hens to dietary lysine and methionine. British Poultry Science 1991;32(5):1069-1088.

Brito C, Dutra J, Dias T, Barbosa L, Nascimento C, Pinto A, et al. Effect of dietary lysine on performance and expression of electron transport chain genes in the pectoralis major muscle of broilers. Animal 2017; 11(5):778-783.
Calabotta DF, Cherry JA, Siegel PB, Jones DE. Lipogenesis and lipolysis in fed and fasted chicks from high and low body weight lines. Poultry Science 1985;64(4):700-704.

Chen S, McMurtry J, Walzem R. Overfeeding-induced ovarian dysfunction in broiler breeder hens is associated with lipotoxicity. Poultry Science 2006;85(1):70-81.

Coon C. The ideal amino acid requirements and profile for broilers, layers, and broiler breeders. St. Louis: American Soybean Association; 2004.

Corzo A, Moran ET, Hoehler D. Lysine needs of summer-reared male broilers from six to eight weeks of age. Poultry Science 2003;82(10):16021607.

Donsbough A, Powell S, Waguespack A, Bidner T, Southern L. Uric acid, urea, and ammonia concentrations in serum and uric acid concentration in excreta as indicators of amino acid utilization in diets for broilers. Poultry Science 2010;89(2):287-294.

Dozier WA, Corzo A, Kidd MT, Tillman PB, McMurtry JP, Branton S. Digestible lysine requirements of male broilers from 28 to 42 days of age. Poultry Science 2010;89(10):2173-2182.

Dozier WA, Corzo A, Kidd MT, Tillman PB, Purswell JL, Kerr BJ. Digestible lysine responses of male broilers from 14 to 28 days of age subjected to different environmental conditions. Journal of Applied Poultry Research 2009;18(4):1056-6171.

Ekmay RD, Salas C, England J, Cerrate S, Coon CN. Lysine partitioning in broiler breeders is not affected by energy or protein intake when fed at current industry levels. Poultry Science 2014;93(7):1737-1744.

Ekmay RD, De Beer M, Mei S, Manangi M, Coon CN. Amino acid requirements of broiler breeders at peak production for egg mass, body weight, and fertility. Poultry Science 2013;92(4):992-1006.

Etches RJ. Reproduction in poultry. Wallingford: CAB international; 1996. p.96-97.

Fisher C. Lysine: amino acid requirements of broiler breeders. Poultry Science 1998;77(1):124-133.

Goldstein D, Skadhauge E. Renal and extrarenal regulation of body fluid composition. In: Whittow GC, Sturkie PD. Sturkie's avian physiology. London: Academic Press; 1998. p.265-297.

Harms R, Ivey F. An evaluation of the protein and lysine requirement for broiler breeder hens. Journal of Applied Poultry Research 1992;1(3):308-314.

Harms R, Russell G. A re-evaluation of the protein and lysine requirement for broiler breeder hens. Poultry Science1995;74(3):581-585.

Harms R, Wilson HR. The chloride requirement of the broiler breeder hen. Poultry Science 1984;63(4):835.

Kang L, Cui X, Yang C, Jiang Y. Identification of miRNAs associated with sexual maturity in chicken ovary by Illumina small RNA deep sequencing. BMC Genomics 2013;14(1):352

Kohn R, Dinneen M, Russek-Cohen E. Using blood urea nitrogen to predict nitrogen excretion and efficiency of nitrogen utilization in cattle, sheep, goats, horses, pigs, and rats. Journal of Animal Science 2005;83(4):879-889.

Mehri M, Kasmani FB, Asghari-Moghadam M. Estimation of lysine requirements of growing Japanese quail during the fourth and fifth weeks of age. Poultry Science 2015;94(8):1923-1927.

Mehri M, Kasmani FB, Asghari-Moghadam M. Digestible lysine requirements of straight-run broiler chickens from fifteen to twenty-eight days of age. Journal of Animal Veterinary Advances 2010;9(17):2321-2324. 
Kim E, Rew HJ, Shin TK, Cho HM,

Wickramasuriya SS, Yi YJ,

Jeong J, Choi I, Heo JM
Mohiti-Asli M, Shivazad M, Zaghari M, Aminzadeh S, Rezaian M, Mateos G. Dietary fibers and crude protein content alleviate hepatic fat deposition and obesity in broiler breeder hens. Poultry Science 2012;91(12):31073114.

Mohiti-Asli M, Shivazad M, Zaghari M, Rezaian M, Aminzadeh S, Mateos G. Effects of feeding regimen, fiber inclusion, and crude protein content of the diet on performance and egg quality and hatchability of eggs of broiler breeder hens. Poultry Science 2012;91(12):3097-3106.

NRC - National Research Council. Nutrient requirements of poultry. $9^{\text {th }}$ ed. Washington: National Academy Press; 1994.

Nørgaard JV, Pedersen TF, Soumeh EA, Blaabjerg K, Canibe N, Jensen BB, et al. Optimum standardized ileal digestible tryptophan to lysine ratio for pigs weighing 7-14kg. Livestock Science 2015;175:90-95

Onagbesan O, Metayer S, Tona K, Williams J, Decuypere E, Bruggeman $V$. Effects of genotype and feed allowance on plasma luteinizing hormones, follicle-stimulating hormones, progesterone, estradiol levels, follicle differentiation, and egg production rates of broiler breeder hens. Poultry Science 2006;85(7):1245-1258.

Pesti GM, Vedenov D, Cason JA, Billard L. A comparison of methods to estimate nutritional requirements from experimental data. British Poultry Science 2009;50(1):16-32.

Powell TS, Gehle MH. The effect of dietary tryptophan and niacin levels on broiler breeder pullets. Poultry Science 1975;54(5):1438-1442.

Rekaya R, Sapp R, Wing T, Aggrey S. Genetic evaluation for growth, body composition, feed efficiency, and leg soundness. Poultry Science 2013;92(4):923-929
Standard Body Weight and Serum Estradiol and

Progesterone Concentrations in Response to Total Lysine Content in Female Broiler Breeders from 14 to 42 Days after Hatch

Reyer $\mathrm{H}$, Hawken R, Murani E, Ponsuksili S, Wimmers K. The genetics of feed conversion efficiency traits in a commercial broiler line. Scientific Reports 2015;5:16387.

Robinson F, Wilson J, Yu M, Fasenko G, Hardin R. The relationship between body weight and reproductive efficiency in meat-type chickens. Poultry Science 1993;72(5):912-922

Scott ML, Nesheim MC, Young RJ. Nutrition of the chicken. Ithaca: Scott and Associates; 1976

Sharp PJ. A comparison of variations in plasma luteinizing hormone concentrations in male and female domestic chickens (Gallus domesticus) from hatch to sexual maturity. Journal of Endocrinology 1975:67(2):211-223.

Si J, Fritts CA, Burnham DJ, Waldroup PW. Relationship of dietary lysine level to the concentration of all essential amino acids in broiler diets. Poultry Science 2001;80(10):1472-1479.

Sibbald IR, Wolynetz MS. Effects of dietary lysine and feed intake on energy utilization and tissue synthesis by broiler chicks. Poultry Science 1986;65(1):98-105.

Siiteri PK. Adipose tissue as a source of hormones. The American Journal of Clinical Nutrition 1987;45(1):277-282.

Tanabe $\mathrm{Y}$, Nakamura T, Tanase $\mathrm{H}$, Doi $\mathrm{O}$. Comparisons of plasma $\mathrm{LH}_{\text {, }}$ progesterone, testosterone and estradiol concentrations in male and female chickens (Gallus domesticus) from 28 to 1141 days of age. Endocrinologia Japonica 1981;28(5):605-613.

Wickramasuriya SS, Yi YJ, Yoo J, Kim JC, Heo KN, Heo JM. Lysine requirements of Korean native ducklings for three weeks after hatch. Journal of Applied Poultry Research 2016;25(4):464-473. 